\title{
Principals' experiences in the implementation of the English Language Proficiency Programme in Namibia
}

\author{
Haaveshe Ndeutalala Nekongo-Nielsen \\ Department of Contemporary Social Issues, \\ University of Namibia, Windhoek, Namibia, and \\ Elizabeth Ndeukumwa Ngololo \\ Department of Educational Research, Multidisciplinary Research Centre, \\ University of Namibia, Windhoek, Namibia
}

ELPP in

Namibia
Received 13 July 2018 Revised 2 October 2018

28 March 2019

17 June 2019

29 July 2019

9 August 2019

17 August 2019

21 August 2019

Accepted 22 August 2019

\begin{abstract}
Purpose - Namibian principals are usually placed in leadership positions without orientation and are found to lack skills to supervise teachers in delivering instruction using the English language. Studies conducted elsewhere in the world found that effective school leadership is needed for the success of professional development programmes. The purpose of this paper is to explore principals' lived experiences with regard to their roles in the implementation of the English Language Proficiency Programme (ELPP).

Design/methodology/approach - This paper followed a qualitative inquiry with multiple case study designs to explore principals' lived experiences during the implementation of the ELPP. Ten schools were selected for the analysis, two from each of the five regions. The schools were selected on the basis of remoteness, the total number of teachers who participated in the ELPP, school phases (i.e. primary and combined) and pre-test scores. Principals were interviewed using exploratory open-ended questions, and data analysis produced five categories under which the results were presented.

Findings - The findings indicate that principals applied their individual logic to accommodate and implement the programme. They applied their individual productive leadership habitus to contextualise ELPP activities to ease their workload and appear corporative. Principals had significant influence on teacher learning and ensured successful implementation of a ministerial programme. Moreover, their leadership skills influenced the ways in which teachers received instruction and created a conducive learning environment. Owing to principals' administrative, instructional and transformational leadership, many teachers participated and transcended upward and some were declared proficient in English.

Research limitations/implications - This study research the effectiveness of leadership regarding English professional development programmes in achieving goals, explore power relations between school principals and education officials when developing and implementing professional development programmes and establish more efficient ways of providing a better leadership model for professional development programmes to achieve goals.

Practical implications - This paper was limited to a few principals at rural schools in selected regions, therefore findings could not be generalised.

Social implications - There is a need for creating opportunities for interactions among all stakeholders who are involved in the development and implementation of English proficiency programmes and to build power relations and work as a team to benefit schools. In order to enhance programme implementation and improve learning outcomes, there is also a need to provide feedback at intervals and find solutions to challenges as a team.

Originality/value - Placing principals in situations without orientation triggered the need for specific leadership logic and particularities to be applied in a context for the success of the programme, which resulted in participation of more teachers in the ELPP. They applied their particularities and productive habitus through administrative, instructional and transformational leadership to enhance learning. Principals appointed English language teachers to instruct and mentor others, and consequently enabled some principals and teachers to exit the programme. Principals achieved these short wins upon realising that one has to cooperate with the authority to ensure achieving desired outcomes.

Keywords School leadership, English Language Proficiency Programme, Logic of practice, Principals' experiences, Productive leadership habitus, Teacher professional development programmes Paper type Research paper
\end{abstract}

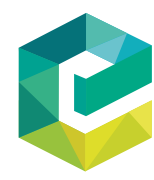

Journal of Educational Administration
Vol. 58 No. 1,2020 pp. $81-95$ (c) Emerald Publishing Limited 0957-8234 DOI 10.1108/JEA-06-2018-0113 


\section{Introduction}

Namibian school principals lack the capacity to provide appropriate leadership in the implementation of language professional development programmes. Principals are expected to "exercise significant influence on teacher professional development" (Bredeson and Johansson, 2000, p. 385) and should have the capacity to provide appropriate leadership (Darling-Harmond et al., 2007; Hallinger and Heck, 2003). However, a lack of initial leadership preparation and professional development as well as contextual issues impede rural principals from carrying out their diverse responsibilities effectively (Clarke and Wildy, 2004; Du Plessis, 2017). Thus, institutional, community, national, cultural, economic and political factors may influence leadership within a school (Hallinger and Heck, 2003).

Namibian principals demonstrated inconsistency on how they understood their leadership roles (Hausiku, 2015), having ascended to leadership positions without orientation for principalship or formal certification, but mainly on the basis of having good classroom teachers and adequately carrying out their administrative duties (Government of the Republic of Namibia, 2007). Pomuti and Weber (2012) further revealed that Namibian principals lack the leadership capacity to make focused decisions. As a result, they continue to use authoritarian leadership styles, resist interference in the daily management of their schools and are reluctant to assist or collaborate with other schools (Pomuti and Weber, 2012). On the other hand, researchers noted that there have been a few published studies on the development and leadership of language professional programmes and the evaluation of such programmes is not common (Coskun and Daloglu, 2010; Day, 1991; OECD, 2009; Samson and Collins, 2012; Weir and Roberts, 1994).

The purpose of the paper was to explore principals' practices in leading and managing the implementation of the English Language Proficiency Programme (ELPP) at Namibian rural schools. The paper emanates from the summative evaluation of the ELPP conducted by the authors in 5 of Namibia's 14 regions. It reviewed Bourdieu's propositions on educational leadership to establish how principals could strategically direct their actions, practices and responsibilities towards realising set goals and serve as instructional and transformational leaders for their schools. It is expected that this paper will contribute to the literature on principals' ability to adapt their leadership skills to the context of individual schools in order to achieve implementation objectives of teacher professional development programmes.

\section{Literature review}

The paper draws on Bourdieu's view of educational leadership to understand the practice of programme development and implementation (Eacott, 2010c, 2013; Lingard and Christie, 2003; Lingard et al., 2003). Bourdieu (1998) views educational leadership as complex, consisting of logic of practice, particularities, strategies and habitus that determine whether principals' actions constitute leadership. Leadership is applied in this study to recognise the social space within which principals work as well as explore their experiences and realities. As they operate within their contexts, "principals sit within the educational field at a point between the policy producing apparatus and the practices of schooling [...] and they have to negotiate various logics of practice" (Lingard and Christie, 2003, p. 327). Bourdieu's logic of practice recognises that sometimes principals are not trained and therefore might not possess the expertise required to successfully perform a given function. For instance, schools in rural areas may pose different challenges on principals which could demand change in strategy and action in terms of service delivery and resources mobilisation. Principals might experience lack of resources and support from their superiors.

Also, if principals are not provided with guidelines, they are likely to interpret and exercise own understanding of the required actions, especially in rural schools where support is inadequate. Principals therefore struggle in applying their minds to given circumstances in 
order to succeed. Bourdieu (1980) notes that existing conditions and practices produce habitus of durable and transposable (replicable) dispositions that leads to desired outcomes. Such practices, however, first need to be defined in relation to the objective to be achieved. Thus, principals make a difference if they are provided with a supportive environment and granted autonomy to make decisions for the purposes of school improvement (Hallinger and Heck, 2003; Hallinger, 2011, 2018; Pont et al., 2008; Robinson, 2007).

Through professional development, existing conditions could be improved to produce the necessary productive leadership that suits desired situations. Successful teacher professional development programmes require "strong, directive leadership focused on instructions from principals" (Hallinger, 2003, p. 329) to encourage and celebrate learning (Bredeson and Johansson, 2000) and instil the habitus needed to work towards a common goal (Bourdieu, 1980). In this paper, instructional and transformational leadership models work simultaneously to enhance learning through the professional development programme. According to Bredenson and Johansson, instructional leadership focuses on the design of professional development aimed at influencing teachers to improve learning. They have identified four areas where principals have substantially impacted and influenced teacher professional development, which are as follows: (i) "principals as instructional leaders and learners; (ii) the creation of a learning environment; (iii) principals' direct involvement in the design, delivery and content of professional development; and (iv) the assessment of professional development outcomes" (Bredeson and Johansson, 2000, p. 385).

Through coordinating and monitoring teacher' performance during professional development programmes, principals could use their authority to influence teachers' learning and participation in the programme. When principals have instructed teachers, change and innovation might occur and result in a shared vision and commitment (Hallinger, 2003). Transformational leadership is important in developing a shared vision and the school capacity for teaching and learning, thereby creating a learning culture (Darling-Harmond et al., 2007; DeMonte, 2013; Hallinger and Heck, 1998, 2003; Robinson, 2007; Witziers et al., 2003). Robinson (2007) points out that high achieving schools tend to have transformational leaders who are active in teacher learning and positively influencing teachers' attitudes and perceptions as well as the school climate. However, principals have to be aware of other external and internal factors that might impact the change process (Hallinger, 2003, 2018).

Both instructional and transformational leadership models are linked to the external environment and school contexts (Hallinger, 2003) and both might be used to motivate teachers to participate in professional development initiatives with the aim of producing positive outcomes. Kotter (1995) suggests that for change to be successful, it requires creating a new system. New systems demand innovative change champions, who will work to create a sense of urgency for the majority of partners to buy-in. Bourdieu (1980) is of the opinion that logic of practice presents moments of innovation appropriate to achieve set objectives and enable leaders to transform their institutions and attain full potential. Principals should therefore be responsible for cultivating motivation, building trust and respect as well as sharing the vision among teachers to increase acceptability of professional development programmes. In so doing, principals may reproduce valuable social and cultural qualities in their teachers (Bourdieu, 1998) through professional development activities and consequently transform leadership to bring about change.

Eacott (2010) maintains that educational systems should consider principals who have pre-requisites and right qualifications for the principalship, so that they are aware of the multiple influences on practice and context. The application of instructional leadership provides guidance for curriculum, assessment and teaching methods to enact the vision of the programme. Principals should have the capacity to understand and interpret the curriculum, serve as mentors and advocate the credibility of the programme. Positive results 
JEA

58,1

would, however, be achieved through transformational leadership, by eliciting individual commitment for enhancing learning and subsequently school improvement. In addition, the practice of principalship is thought to be influenced both by the logic of practice and capacities of partners.

Getting a buy-in from those involved and affected by the proposed changes necessitates involving the right people. Principals should therefore serve as influential players in the sector and take measured risks in a struggle for power over how professional development programmes are offered at their schools. In that respect, principals are required to establish followership, build new relationships as well as cultivate essential habits and the willingness to challenge the status quo by changing their logic of practice and transforming implementation strategies to suit their schools' contexts. Therefore, teacher professional development calls for negotiation and collaboration between principals and teachers for improved communication, increased participation, enhanced learning as well as aggressive resource mobilisation and marketing of programmes. This type of collaborative efforts could lead to successful implementation of professional development programmes and activities.

Walter and Briggs (2012) maintain that "teachers' professional development makes the most difference when it is supported by effective school leadership" (p. 1). The OECD (2009) specifically advises that better support for teachers by principals is needed for being able to participate fully in English language professional development programmes. The authors used Bourdieu's work to critically explore the interactions between the practices of principals endowed with different power structures, exercise of influence over others and logic of practice within the context of the Namibian educational system. In so doing, the authors take cognisance of principals' individual productive habitus, logic of practice, strategies and the particularities of each school and draw a general analysis of leading learning in view of the ELPP implementation. This paper reports on principals' experiences and realities on how they led and managed continuous professional development activities in rural schools. Questions on "why" and "how" were asked to understand the phenomenon of educational leadership within the overall research question of "how did principals lead and manage programme implementation and what were their experiences". The main research questions that guided this study were:

$R Q 1$. How did principals experience their roles in the ELPP implementation process? (a) Why did they participate in the programme? (b) What systems were set up in the regions and at school level to coordinate programme implementation?

$R Q 2$. How did principals influence teacher participation and learning as well as the overall implementation process?

\section{Context}

After Namibia's independence in 1990, English was adopted as an official language with a view to unite Namibian people behind one language (Chavez, 2016; Harlech-Jones, 1990, 1998; Ministry of Education and Culture (MEC), 1993). Subsequently, English became the medium of instruction in schools as stated in the Language Policy for Namibian Schools (MEC, 1993). The development and adoption of the Language Policy for Namibian Schools took into account the fact that Namibia is a multilingual society with 14 written languages, including the sign language (Education Management Information System (EMIS), 2015; Frydman, 2011; MEC, 1993). The Language Policy for Namibian Schools specified that from Grade 1 to 3 children would be taught in their mother tongue, whereas from Grade 4 to Grade 13 all subjects would be taught in English (MEC, 1993). It should be noted that the Namibian school system is categorised in grades (i.e. Grades 0-13). However, the Language Policy was implemented without teachers being fully prepared to teach in English as a medium of instruction (Freeman, 2016; Frydman, 2011; Harlech-Jones, 1990, 1998). Also, at the time of 
independence, only about 0.8 per cent of the Namibian population spoke English as a mother tongue (Brock-Utne and Holmarsdottir, 2001; Frydman, 2011; Putz, 1995).

It is a norm that teachers must possess proficient English language skills to enable them to teach different subjects effectively and meet rigorous standards. Nevertheless, over the years, standards have not been met, partly owing to limited knowledge and lack of confidence amongst Namibian teachers to use English (Harlech-Jones, 1998; Lyamine and Mlambo, 2016; Ministry of Basic Education, Sports and Culture, 2000, 2001; Sukumane, 2000; Tötemeyer, 2010; Wolfaardt and Schier, 2011). It was confirmed that the low level of English proficiency among teachers was a contributing factor to the poor performance and the low achievement of learners in external examinations (Simasiku et al., 2015; Tötemeyer, 2010; Wolfaardt, and Schier, 2011). In addition, results of a test by the Ministry of Education in 2010 indicated that 98 per cent of Namibian teachers were not proficient in the English Language (Kisting, 2011). In an effort to address this shortcoming, the ELPP was developed and implemented to upgrade and improve teachers' and principals' proficiency in English.

The evaluation ELPP implementation was conducted in 2016 to assess and determine its success in terms of teachers' views on the impact (Ngololo and Nekongo-Nielsen, 2017) and principals' capacity to lead the programme. This paper explained that the programme was divided into the Pre-intermediate, the Intermediate, the Advanced and the Proficient. The framework within which the programme was implemented had established a three-tiered administration and coordination structure, constituted at national, regional and school levels. Nationally, an implementing agency was set up and overseen by the Project Steering Committee, comprised of membership drawn from the Ministry of Education, the implementing agency and a teachers' union. The Project Steering Committee was responsible for reviewing and approving implementation plans, resources, timeframes and the scope of activities. Two programme administrators were tasked with the overall administration and coordination of the programme at national level. Regionally, there were area managers who liaised between the implementing agency and schools; ensuring the dissemination of information to schools, dispatching of study materials, test papers and certificates. At school level, principals were tasked to provide the overall leadership of the implementation process and expected to facilitate all programme activities (Fourie and Kemanya, n.d.).

\section{Methods}

This study followed a qualitative inquiry to provide a holistic and deeper understanding of the lived experiences of school principals during the implementation of the ELPP. The authors conducted multiple interviews with diverse principals to explore their experiences, using exploratory open-ended interviews (Creswell, 2014). The phenomena in the ELPP were described, explicated as interpreted and deduced from the summative evaluation with reference to principals' experiences. The population of the study comprised of principals from 14 educational regions in Namibia. These regions had a total of 1,782 principals, with 1,519 primary and combined school principals who were employed by the Ministry of Education and in private schools (EMIS, 2015). In Namibia, combined schools comprised of both the primary and junior secondary phases (Grades 1-10).

A convenience sampling procedure was used to select the five regions of Erongo, Hardap, Khomas, Ohangwena and Omusati on the basis of their accessibility with regard to the vastness of the regions and the distance between schools (Ngololo and Nekongo-Nielsen, 2017). Using a stratified purposive sampling procedure, 10 out of 40 schools were selected for the analysis, two from each of the five regions. Schools were selected on the basis of remoteness (rural), higher participation of teachers in the ELPP, school phases (i.e. primary and combined) and pre-test scores. The paper includes the analysis of the selected ten principals from the chosen ten rural schools, including those who participated in the programme and those who did not, as long as their teachers participated. 
Using an open-ended interview guide, each principal was interviewed for about an hour on the role played, emphasising the constructs of participation, planning, design and content development; delivery of instruction; administrative leadership; instructional leadership and programme outcomes. These constructs provided the frame within which to discuss the logic of practice applied by principals in an attempt to improve teachers' language proficiency. Interviews were recorded and transcribed. The analysis used a bracketing method, where data were taken apart in search of commonalities and dissected to discover emerging themes. Specifically, the data were located within personal experiences and relevant statements by the principals in relation to the process and output of the programme. Individual experiences typically add depth, detail and a degree of personalised outcomes regarding the quality of the programme (Patton, 2002), thereby rendering the overall judgement about the effectiveness of the programme.

\section{Results}

To improve interpretation, enrich the analysis and arouse the reader's conceptual interest, all data were merged and coded into themes that reflect relevant principals' experiences, which featured in the final analysis and under which the results are presented (Creswell, 2014). Furthermore, a structural description was adopted to present the collective experiences of all principals on how they viewed the programme, their efforts in ensuring the implementation process and their expectations for what the programme achieved (Patton, 2002). The results are therefore presented in themes at the description level, which are indicative of principals' reflections regarding the phenomenon of educational leadership and are organised in subheadings of: principals' involvement and direct participation; principals' influence over others and the learning environment; and principals' assessment of programme outcomes. Relevant quotes were cited, indicating the nature of the data captured and the effects of leadership on teachers and the learning environment.

\section{Principals' involvement and direct participation}

The summative evaluation established that none of the principals were involved in the planning, design and content development of the programme. As a result, six principals found the programme ill-planned, not well introduced and that it affected learning negatively. Principals observed that it seemed the Ministry of Education and all other parties involved did not have the same understanding in terms of how to roll out the ELPP. One principal seemed to summarise others' opinion when he said:

The programme was not very well introduced. Nobody came from the Ministry of Education to introduce the programme to teachers at schools, only messages were sent to principals to demand all teachers to actively participate.

Principals expected the Ministry of Education's high ranking officials to introduce the programme to participants. Instead, it was introduced by area managers (people recruited on a part time basis), and in some cases, by regional contact persons who were at the level below Regional Directors. One primary school principal saw himself as:

[...] a good marketer of the programme, because the Ministry of Education officials did not take that responsibility upon themselves. [...] we wanted to see the Ministry of Education Headquarters' staff leading the campaign or even an accompanying official communique signed by the Minister.

Furthermore, it was established that principals, especially those from combined schools, were graded at the advanced level in the pre-test, in terms of proficiency; a level they thought was good enough. Since the programme was based on voluntary participation, after the pre-test, six of the ten principals did not participate in the programme nor did they write further tests, as they were not interested in reaching the proficiency level. Four principals 
participated, of whom three were graded at the advanced level and reported not to have attended the face-to-face sessions because there were none organised for that level. Only one primary school principal attended the face-to-face sessions, stating:

Since I was graded at the Pre-intermediate in the pre-test, I had to attend the face-to-face, but I found the tutoring time of the 2-3 hours per Saturday too short to enable me to understand the subject matter.

In spite of this, all ten principals provided information reported in this paper. Principals' nonparticipation has affected teachers' participation rate, because schools whose principals did not participate in the programme recorded low attendance:

"Not all teachers took part because the Government forced the programme on them, resulting in the teachers' union interfering and preventing some principals and teachers from participating", noted one principal.

Results further indicated that all primary school principals discouraged Grade 1 and the about-to-retire teachers from participating in the programme. It should be noted that Grades 1-3 teachers use indigenous languages as a medium of instruction. Principals argued that the design of the programme overlooked the age and school phase factors. A primary school principal summarised the reasoning in these words:

[...] the programme [...] did not address the learning needs of Grade 1 teachers who teach in indigenous languages and [...] those who reached retirement age. They should have exempted these teacher categories from the programme. I agreed with my Grade 1 teacher and the two who were about to retire when they refused to participate in the English Language Proficiency Programme.

Whether participated or not, principals managed to skim through parts of the study materials and found them valuable and useful as self-study packs. They acknowledged the quality of the learning materials as relevant for classroom teaching and as reference materials by teachers engaged in further studies to obtain higher qualifications and/or for their children attending university. They found that the study materials addressed teachers' learning needs of grammar, vocabulary building, correct speech and pronunciation as well as general language usage:

"The study materials were very good; I found the content of the programme empowering as it provided grammatical, vocabulary knowledge $[\ldots]$ and did well in addressing language barriers reading, writing $[\ldots]$ and improving language use - thereby eradicating grammatical errors", exclaimed a Combined School principal.

Another principal reported that:

I sometimes overhear in the staffroom and during meetings correcting themselves when conversing in English [...] some of my colleagues are now engaged in self-study and self-reading as a result of participating in the programme.

Principals however reported that the reading, writing and listening activities were out of the Namibian context. One primary school principal complained:

[...] some content was out of the Namibian context, especially regarding reading and listening. Also, topics for the writing component were irrelevant to teachers' needs [...] not applicable to the Namibian situations and not familiar to participants.

The principal who attended the face-to-face sessions also complained that there was not enough time for reading through copious study materials:

I did not manage to go through [complete] that Bible and I found the study materials very difficult to understand and the language used was hard for me. 
The content of the intermediate level was especially found to be too advanced and found the listening part most difficult to comprehend. As the principal reiterated:

$[\ldots]$ some accents were foreign - voices were different [...] and not familiar to most participants [...] they were not Namibian English, our Namlish accent.

Principals reported that CDs were not useful because there was no electricity at schools in deep rural areas. It meant that participants would not have been able to read the study materials during their free time as principals lived and commuted from rural villages. Principals, however, found the stories of wild animals, weather conditions and war zone interesting and relevant to everyday life. Principals further complained that there were not enough oral activities to practise speaking:

"[...] considering that teachers spend most of the time in front of learners talking, I mean teaching is nothing but speaking. You would then think there would be a lot of oral exercises in the study guide to enable teachers to practise their speaking", stated a Combined School principal.

Principals further observed that tests, including the pre-test, were difficult, with very long reading passages and writing activities. They equated the length of tests to "writing a thesis":

"I wondered whether it was a Master's thesis I was writing, and not a test for English writing, my hands got tired", complained a Combined School principal.

Principals alleged that some test questions, especially for the advanced level, were pitched at a higher level. In this regard, they wondered whether the programme was testing "general knowledge" instead of "English proficiency". They also noted that the time allocated for the listening test was not enough and that some participants needed to listen to the CD twice.

\section{Principals' influence over others and the learning environment}

Principals reiterated that they did not own the programme because they were only oriented to the programme through written communiques from the Ministry of Education and the implementing agency, as opposed to face-to-face sessions:

"Given that we were never briefed face-to-face as to what was expected from us regarding the implementation of the English Language Proficiency Programme. These responsibilities added an extra load to our already busy schedules and were time consuming". The communiques "requesting us to carry out administrative duties, sent via the Regional Offices, were not always clear regarding how and when they want us to attend or arrange all these activities", complained a Combined School principal.

Despite not being properly consulted or fully involved in the programme design and planning, principals had to carry out their duties as expected, sometimes on a non-working day such as a Saturday. They carried out their administrative responsibilities, which included sensitising teachers about the importance and contribution of the programme to realise the educational policy goals in the country; ensuring that teachers register and actively participate; recording the number of study materials received; identifying and recruiting suitable school facilitators; recommending qualified tutors to facilitate face-to-face sessions; ensuring that no one interferes with teachers' participation; administering tests; and providing feedback to programme administrators as per the reporting requirements. In order to lessen the burden of a heavy administrative load, principals appointed English language teachers as facilitators to assist with this added responsibility, though principals remained in authority.

Principals noted that the administration and logistics of organising Saturday classes, far away from some schools, prevented some teachers from attending contact sessions:

"Saturday classes really discouraged most teachers from attending and benefiting from the face-toface sessions", criticised a principal. 
In addition, participants were made to sit on child-sized chairs as one principal aired her sentiments:

$[\ldots]$ how can we be made to sit on learners' chairs? Some of us were uncomfortable in these childsized chairs.

As Saturday sessions did not work for some schools, principals made alternative arrangements by organising contact sessions after school hours and/or during school holidays. Principals discovered that teachers were tired after hours; and during school holidays teachers should spend vacations with their families. In all cases, principals observed other impediments such as transportation not being provided to participants to reach venues, no refreshments were offered and, worst of all, participants (teachers and principals) were forced to sit on child-sized chairs, which made them extremely unhappy. Nonetheless, principals used a variety of strategies to recruit teachers in the programme, motivated them to study hard and empowered them to take tests. For example, they used humour to remove the negative connotation teachers had towards the programme; organised study mini assemblies and/or weekly workshops for the levels of pre-intermediate, intermediate and advance; and used meetings to promote the programme. One principal said that she:

[...] motivated teachers to participate by praising those who passed and progressed to the next level. [She enticed them] [...] you know, one always stands to gain from a new programme. I discovered that there are a lot of things in the programme that I did not know before. I am learning something new every day, even though I did not understand the purpose from the beginning.

They further facilitated learning by motivating and communicating the need for the programme to the teachers. A primary school principal told her teachers that:

[...] the programme will enable you to improve your English proficiency and become more confident and a better teacher. It will also enable me, as a principal, to be aware of the difficulties you experience in communicating learning materials to learners [...]

Sadly, principals established that tutors recruited to facilitate face-to-face intermediate sessions were not suitable to teach adult learners:

"I found that tutors did not always correctly follow timetables and classes were sometimes called off. Our tutor was also not very proactive, he left us in the dark about the programme content and this was demotivating to us", said a Combined School principal who purposely attended contact sessions.

Principals further noted that most primary teachers found the test items difficult and the assessment process unfair. Three principals who were conversant with the English language have thus taken it upon themselves to provide pedagogical support, in addition to their administrative duties. "I took my teachers through the study materials and prepared them for tests", reported a primary school principal who also assumed the role as an English teacher. At another school, when a principal discovered the learning areas where her teachers were experiencing difficulties, she said:

I requested the language teacher to arrange classes once a week to address the specific topics where teachers were experiencing problems.

Principals were thus happy to see some of their teachers progressing to advanced levels of proficiency. As one combined school principal reiterated:

[...] due to principals' efforts it was pleasing to see that some of the teachers progressed, some were even exempted and English language improved across the board.

Despite the fact that ELPP activities interfered with principals' pre-planned social programmes, they persevered and remained positive. Principals claimed to have gone out of their way to carry 
out their work diligently, sensitising and removing any negativity from teachers' minds. In addition, principals encouraged teachers to attend the face-to-face sessions, which resulted in a good number of them exiting the programme upon being declared proficient. They provided pedagogical support and made it their responsibility to lure dropout teachers into the programme for them to take the required tests. In this respect, principals were thought to have exercised autocratic leadership to the point where teachers threatened to resign from the school and the programme altogether. Although acting out of fear of victimisation by the Ministry of Education officials, principals argued that exerting administrative and instructional leadership ensured that logistical infrastructures were in place for teachers to benefit from face-to-face sessions. Moreover, in all the regions, principals encouraged the formation of study groups among teachers a few days before test dates, a strategy that seemed to have worked and enabled more teachers to progress to advanced levels of English proficiency. Through their efforts, principals felt they facilitated and created a learning culture and conducive atmosphere at their schools. They accomplished this by paying attention to programme objectives, exhibiting positive attitudes to their subordinates and kept reminding teachers of the positive effects the programme could have on their careers.

\section{Principals' assessment of programme outcomes}

Principals understood that the purpose of the programme was to improve the English writing, reading and speaking skills of teachers, enabling them to teach effectively, and subsequently improve teaching and learning at their schools. One combined school principal said:

$[\ldots]$ the most important achievement [...] was the boosting of teachers' morale, especially those who were interested and had progressed from one level to another, and have now proved to themselves that they are proficient in English. As a result of participating in the programme, my unqualified Agriculture teacher got inspired and he has now joined the Advanced Certificate in Education programme to be qualified as a teacher.

Four principals appreciated the programme because it enabled teachers to improve communication skills useful for their administrative duties, and as a result they could delegate some of their duties to heads of department and teachers:

"My teachers gaining skills in these areas, has eased my workload.[...] I am now able to delegate my head of department to draft reports and other official documents while I concentrate on other responsibilities", a statement made by a Combined School principal.

Also, principals noted that teachers who participated in the programme gained confidence and were able to write reports, memos and even their curriculum vitae. In addition, teachers were able to conduct daily devotions in English at morning assemblies, a responsibility usually left to the principal.

According to the principals, another important accomplishment of the programme was the creation of a learning culture at schools. The programme resulted in a healthy competition amongst principals in terms of the number of teachers participating and progressing to the next level. Principals were seen as successful if their schools had the highest number of teachers completing or exiting the programme:

"I am so proud of my teachers, because at one of the regional directors' meeting, my school was singled out as the best for producing more Advanced level teachers", exclaimed an excited Combined School principal.

Principals affirmed that the programme was good for improving teachers' English proficiency and had enabled teachers to earn credits towards higher qualifications. Therefore, principals wanted the programme to be compulsory and continue onsite so that they could enhance their English language skills as well as teaching and learning at their 
schools. In addition, principals concluded that the programme has achieved its goals in addressing and improving language use and believed that it would solve the backlog of failing learners in the country.

\section{Discussion}

The ELPP was introduced to address deficiencies identified in the use of English for teaching. During the implementation, principals were expected to possess decision-making skills, handle emotional issues, appoint the required staff, deal with all technicalities - including motivating teachers to participate and lead programme implementation to its successful conclusion. It meant that, even principals in rural areas had to be open-minded and implement the activities under given circumstances and use strategies that may not have been suitable for their school contexts. Initially, the programme was received with rejection owing to the unsatisfactory communication strategy used by the Ministry of Education. The fact that principals were not oriented in their duties exacerbated the situation and resulted in nonparticipation of some principals and subsequently some teachers. Lack of consultation during the development of the ELPP also led principals to develop negative attitudes towards the programme. They found the programme ill-conceived and wished to have involved in all processes. The exclusion made them feel not valued and caused them to conclude that their input did not matter. Lack of involvement throws people, in leadership, out of balance, not knowing what to do (Eacott, 2013).

Though principals were not prepared for the roles of supervising the implementation process, they eventually understood the purpose of the programme and developed positive habits. They realised that, unless leadership is engaging, it could negatively influence organisational activities and therefore render them irrelevant (Senge, 2006). Principals further recognised that to move to the desired future, one must develop a habit and adopt the logic of practice that sustain durable competencies, dispositions and skills within organisations (Bourdieu, 1980). Hence, principals decided to work on areas where they could have significant influence on teachers' learning and enable subordinates to follow. All principals applied their logic of practice, particularities and habitus, which resulted in more teachers' participation. Strategically, principals took rational actions and applied corrective and coercive actions to convince teachers to participate in the ELPP for their own and schools' benefit (Hallinger, 2018; Fullan, 2001, 2011; Kotter, 1995). Principals also made alternative arrangements regarding face-to-face sessions and appointed English language teachers to instruct and mentor others, and consequently enabled some principals and teachers to exit the programme. Senge (2006) alluded to the importance of leadership in ensuring the achievement of organisational goals by enabling all people to pull in the same direction.

Moreover, principals valued supervisory leadership and recognised that good leaders are those who respect authority, appear corporative, are problem solvers, "appreciate organisations as living systems [...]" (Senge, 2006, p. 321) and guide people in the direction that benefits the organisation. Principals, therefore, evoked their powers, applied their individual productive leadership habitus (Bourdieu, 1980, 1998) and contextualised ELPP activities to ease their workload. Under the given location of their schools and resource limitations, they applied the most appropriate strategy to achieve the objectives of programme implementation by modifying and adapting their logics of practice (Bourdieu, 1980). Some principals opted to participate and accommodate the programme so as not to be seen defying ministerial orders. They exerted the necessary leadership skills that would ensure effective and successful implementation of the programme. Within their institutional contexts, principals exercised administrative leadership that focused on people; helped teachers grow; and created change and a culture of learning (Daft, 2011; Elhajj, 2013). They appointed head of the departments to operationalise the programme and by so doing, 
JEA

58,1

principals have created a situation of dispersal leadership at their schools (Fullan, 2001; Lingard and Christie, 2003).

Principals further went out of their way to motivate and provide teachers with pedagogical support. As instructional leaders, principals supported learning and growth, provided feedback, enticed teachers to remain in the programme and celebrated those who progressed to advanced levels (Hallinger, 2003; Fullan, 2001; Robinson, 2007). They have also tried to build a shared vision by positively influencing teachers' attitudes to think of the ELPP as helping their schools to become effective institutions. Principals' efforts motivated teachers to gain the skills needed for teaching, improvement and sought assistance when required in order to maximise the output. In the process, principals developed the leadership habitus that enabled their practice to be harmonised towards a common goal, and to some extent, assisted their schools to attain the realisation of programme implementation (Bourdieu, 1980).

Within their logics of practice, principals exercised administrative, instructional and transformational leadership for effective implementation of the programme and encouraged teachers to participate regardless. Through leadership that recognises the appropriateness of professional development, principals created short wins. However, a self-evaluation could not be done to establish issues that hindered effective implementation as was reflected in the design of the programme. It is important to make corrections where necessary and provide feedback at intervals (Bredeson and Johansson, 2000; Senge, 2006). Robinson (2007) notes that the act of giving feedback to teachers and the knowledge of what to say about the quality of teaching are important components of institutional leadership development. Feedback during the implementation of professional development programme might serve as the correct process to reproduce valuable qualities (Bourdieu, 1998) among principals and teachers.

\section{Implications}

Allowing principals to lead a programme without orientation required change in individual habitus, specific logic of practice and particularities for its success. In this paper, principals applied their particularities and productive habitus that enabled them to exercise administrative, instructional and transformational leadership to enhance learning. As a result, principals achieved short wins after realising that in order "to secure a chance of success, one has to recognise the implications inscribed in the various relations" (Bourdieu, 1980) and cooperate with authority to achieve desired outcomes.

This study was limited to a few principals at rural schools in selected regions. Therefore, there is a need for a study that includes all regions so that findings could be generalised. There is also a need to establish and classify leadership models and styles that could be applied to specific contexts. Research is further required to establish more efficient ways of providing a better leadership model for English professional development programmes if such programmes are to achieve their goals. Further research is required with regard to monitoring and evaluating strategies to provide feedback about the implementation at intervals, so that challenges are immediately addressed and new strategies can be adopted for the purposes of improvement.

The authors recommend that the outcome of this study can be used by education officials in the Ministry of Education to ensure the availability of guidelines for the development and implementation of future English professional development programmes. Rural school principals need to negotiate power relations with their superiors in order to enhance effective implementation of professional development programmes at their schools. Moreover, there is a need to explore power relations between school principals and education officials with regard to the development and implementation of English proficiency programmes for teachers. 


\section{References}

Bourdieu, P. (1980), The Logic of Practice, Stanford University Press, Stanford.

Bourdieu, P. (1998), Practical Reason, Polity Press, Cambridge.

Bredeson, P.V. and Johansson, O. (2000), "The school principal's role in teacher professional development", Journal of In-Service Education, Vol. 26 No. 2, pp. 385-401.

Brock-Utne, B. and Holmarsdottir, H. (2001), "The choice of english as a medium of instruction and its effects on the African languages in Namibia”, International Review of Education, Vol. 47 Nos 3-4, pp. 293-322.

Chavez, A. (2016), "Rights in education and self-identity: education and language of instruction in Namibia”, International Education Studies, Vol. 9 No. 3, pp. 189-196.

Clarke, S. and Wildy, H. (2004), "Context counts: viewing small school leadership from the inside out", Journal of Educational Administration, Vol. 42 No. 5, pp. 555-572.

Coskun, A. and Daloglu, A. (2010), "Evaluating an english language teacher education program through Peacock's model”, Australian Journal of Teacher Education, Vol. 35 No. 6, pp. $24-42$.

Creswell, J.W. (2014), Research Design: Qualitative, Quantitative and Mixed Methods Approaches, 4th ed., Sage Publications, London.

Daft, R.L. (2011), The Leadership Experience, 5th ed., South-Western, Mason, OH.

Darling-Harmond, L., LaPointe, M., Meyerson, D., Orr, M.T. and Cohen, C. (2007), Preparing School Leaders for a Changing World: Lessons from Exemplary Leadership Development Programs, Stanford University, Stanford Educational Leadership Institute, Stanford, CA.

Day, R.R. (1991), Models and the Knowledge Base of Second Language Teacher Education, National Centre for Research on Teacher Learning, East Lansing, MI.

DeMonte, J. (2013), High-Quality Professional Development for Teachers: Supporting Teacher Training to Improve Student Learning, Centre for American Progress, Washington, DC.

Du Plessis, P. (2017), "Challenges for rural school leaders in a developing context: a case study on leadership practices of effective rural principals", KOERS-Bulletin for Christian Scholarship, Vol. 82 No. 3, available at: https://doi.org/10.19108/KOERS.82.3.2337

Eacott, S. (2010), "Studying school leadership practice: a methodological discussion", Issues in Educational Research, Vol. 20 No. 3, pp. 220-233.

Eacott, S. (2013), “Towards a theory of school leadership practice: a bourdieusian perspective”, Journal of Educational Administration and History, Vol. 45 No. 2, pp. 174-188.

Education Management Information System (2015), Education Statistics, Ministry of Education, Arts and Culture, Windhoek.

Elhajj, S. (2013), "Importance of leadership in administration", Paper Presented at the Duquesne University Conference, 24 September, available at: https:doi:10.13140/RG.2.1.2588.1120

Fourie, G. and Kemanya, E. (n.d.), English Language Proficiency Programme: End of Project Report, UNAM, Windhoek.

Freeman, D. (2016), Educating Second Language Teachers, Oxford University Press, Oxford.

Frydman, J. (2011), "Critical analysis of Namibia's english only language policy”, in Bokamba, E.G., Shosted, R.K. and Ayalew, B.T. (Eds), Selected Proceedings of the 40th Annual Conference in African Linguistics, (ISBN 978-1-57473-446), Cascadilla Proceedings Project, Somerville, MA, pp. 178-189.

Fullan, M. (2001), Leading in a Culture of Change, Jossey-Bass, San Francisco, CA.

Fullan, M. (2011), Change Leader: Learning to do What Matters Most, Jossey-Bass, San Francisco, CA.

Government of the Republic of Namibia (2007), Education and Training Sector Improvement Programme (ETSIP): Planning for a Learning Nation, Government of the Republic of Namibia, Windhoek. 
Hallinger, P. (2003), "Leading educational change: reflections on the practice of instructional and transformational leadership", Cambridge Journal of Education, Vol. 33 No. 3, pp. 329-351.

Hallinger, P. (2011), "Leadership for learning”, Journal of Educational Administration, Vol. 49 No. 2, pp. 125-142.

Hallinger, P. (2018), "Bringing context out of the shadows of leadership", Educational Management Administration and Leadership, Vol. 46 No. 1, pp. 5-24.

Hallinger, P. and Heck, R.H. (1998), "Exploring the principal's contribution to school effectiveness: 1980-1995", School Effectiveness and School Improvement, Vol. 9 No. 2, pp. 157-191.

Hallinger, P. and Heck, R.H. (2003), "Understanding the principal's contribution to school improvement", in Wallace, M. and Poulson, L. (Eds), Learning to Read Critically in Educational Leadership and Management, Sage, London.

Harlech-Jones, B. (1990), "Language and the constitution”, Facetten, Vol. 9 No. 2, pp. 21-25.

Harlech-Jones, B. (1998), “Viva english! or is it time to review language policy in education?”, Journal for Education Reform in Namibia, Vol. 6, pp. 1-10.

Hausiku, S.E. (2015), “An investigation into the relationship between school leadership and learners' academic performance at four secondary schools in the Kavango Region, Namibia", Unpublished Thesis for the Degree of Master of Education in the Department of Education Policy Studies, University of Stellenbosch, Western Cape, available at: https://scholar.sun.ac.za/ bitstream/handle/10019.../simanu_investigation_2015.pdf?... (accessed 11 March 2019).

Kisting, D. (2011), "98\% of teachers not fluent in english", The Namibian Newspaper, 09 November 2011, p. 1.

Kotter, J.P. (1995), "Leading change: why transformation efforts fail", Harvard Business Review, available at: https://wdhb.org.nz/contented/clientfiles/whanganui-district-health-board/files/ rttc_leading-change-by-j-kotter-harvard-business-review.pdf (accessed 11 August 2018).

Lingard, B. and Christie, P. (2003), "Leading theory: bourdieu and the field of educational leadership. An introduction and overview to this special issue", International Journal of Leadership in Education, Vol. 6 No. 4, pp. 317-333.

Lingard, B., Hayes, D., Mills, M. and Christie, P. (2003), Leading Learning, Open University Press, Berkshire.

Lyamine, Y. and Mlambo, N. (2016), “Opportunities granted or denied: an analysis of teachers' implementation of English Language syllabus' learning objectives and the fate of grade 10 ESL learners at public schools in Windhoek", Journal for Studies in Humanities and Social Sciences, Vol. 5 No. 2, pp. 50-65.

Ministry of Basic Education, Sports and Culture (2000), English Language Proficiency of Namibian Teachers: Report on Research into English Language Proficiency of Teachers/Student teachers and Basic Education Principals and Teachers' Perceptions of the Use of English in Namibian Schools, Ministry of Basic Education, Sports and Culture, Windhoek.

Ministry of Basic Education, Sports and Culture (2001), Feasibility Study on the English Language Proficiency of Namibian Teachers, Ministry of Basic Education, Sports and Culture, Windhoek.

Ministry of Education and Culture (MEC) (1993), The Language Policy for Schools: 1992-1996 and Beyond, Longman, Windhoek.

Ngololo, E.N. and Nekongo-Nielsen, H. (2017), "Teachers' views on the implementation of the english language proficiency programme in Namibia”, International Education Studies, Vol. 10 No. 11, pp. 155-163.

OECD (2009), "The professional development of teachers", in Organisation for Economic Cooperation Development (Ed.), Creating Effective Teaching and Learning Environments: First Results from TALIS, OECD, Brussels.

Patton, M.Q. (2002), Qualitative Research and Evaluation Methods, 3rd ed., Sage Publications, Thousand Oaks, CA. 
Pomuti, H. and Weber, E. (2012), "Decentralization and school management in Namibia: the ideologies of education bureaucrats in implementing government policies", International Scholarly Network, available at: www.researchgate.net/publication/258404308_ Decentralization_and_School_Management_in_Namibia_The_Ideologies_of_Education_ Bureaucrats_in_Implementing_Government_Policies (accessed 11 March 2019).

Pont, B., Nusche, D. and Moorman, H. (2008), Improving School Leadership: Volume 1: Policy and Practice, OECD, Brussels.

Putz, M. (1995), Discrimination through Language in Africa? Perspectives on the Namibian Experience, Mouton de Gruyter, Berlin.

Robinson, V.M. (2007), "The impact of leadership on student outcomes: making sense of the evidence", A keynote address presented at the 2007 Research Conference on The Leadership Challenge: improving learning in schools, Australian Council for Educational Research, Melbourne, available at: https://research.acer.edu.au/cgi/viewcontent.cgi?article=1006\&context=research_ conference_2007 (accessed 11 August 2018).

Samson, J.F. and Collins, B.A. (2012), Preparing All Teachers to Meet the Needs of English Language Learners: Applying Research to Policy and Practice for Teacher Effectiveness, Center for American Progress, Washington, DC.

Senge, P.M. (2006), The Fifth Discipline: The Arts and Practice of the Learning Organisation, Random House, London.

Simasiku, L., Kasanda, C. and Smit, T. (2015), "Teaching subjects matters through English as the medium of instruction in the Namibian English second language classroom”, European Scientific Journal for Studies in Humanities and Social Sciences (Special Edition), Vol. 1, pp. 1857-7881.

Sukumane, J.B.G. (2000), "Issues in language policy and planning: the case of Namibia", Studies in Linguistic Sciences, Vol. 30 No. 2, pp. 199-208.

Tötemeyer, A.-J. (2010), "Multilingualism and the language policy for Namibian Schools", PRAESA (Project for the Study of Alternative Education in South Africa), Cape Town.

Walter, C. and Briggs, J. (2012), What Professional Development Makes the Most Difference to Teachers: A Report Sponsored by the Oxford University Press, University of Oxford Department of Education, Oxford.

Weir, C. and Roberts, J. (1994), Evaluation in English Language Teaching, Blackwell, Oxford.

Witziers, B., Bosker, R.J. and Krüger, M.L. (2003), "Educational leadership and student achievement: the elusive search for an association", Educational Administration Quarterly, Vol. 39 No. 3, pp. 398-425.

Wolfaardt, D. and Schier, C. (2011), "Report on the findings of the needs assessment survey", Ministry of Education, Windhoek.

\section{Further reading}

Barley, Z. and Beesley, A.D. (2007), "Rural school success: what can we learn?”, Journal of Research in Rural Education, Vol. 22 No. 1, pp. 1-16.

Farsi, M. and Sharif, M. (2014), "Stufflebeam's CIPP model and program theory: a systematic review", International Journal of Language Learning and Applied Linguistics World, Vol. 6 No. 3, pp. 400-406.

\section{Corresponding author}

Haaveshe Ndeutalala Nekongo-Nielsen can be contacted at: hnnielsen@unam.na

For instructions on how to order reprints of this article, please visit our website:

www.emeraldgrouppublishing.com/licensing/reprints.htm

Or contact us for further details: permissions@emeraldinsight.com 